\title{
Censorship Towards Czeslaw Miloszin Poland in the Fifties after Having Chosen the Emigration
}

The significant position of Czesław Miłosz in the Polish literary environment shaped after the war caused determined that his voice would be acknowledged as one of the most important in discussions about the condition of poetry and its function towards experiences of occupation ${ }^{1}$. It did not change after he chose emigration. Although officially Miłosz's decision was condemned by many critics and poets, the author of Rescue and A Moral Treatise was still treated as an authority.

To the question, did the breakdown of the communist government happen at the right time, Miłosz responded:

Nie wiem. Ta sprawa była szalenie bolesna, trudna. Myśląc z perspektywy nie wydaje mi się, że wtedy była decyzja jakaś jednoznaczna do powzięcia. Teraz, jak myślę wstecz, jak myślę z perspektywy, to widzę, jak trudno było powiedzieć, co trzeba było zrobić. Ale równocześnie przez cały czas, kiedy byłem w służbie Polski Ludowej, dręczyły mnie wyrzuty sumienia, ponieważ świadomość [...] tego, co się działo, miałem bardzo ostrą, być może ostrzejszą niż większość moich kolegów literatów ze względu na znajomość rosyjskiego i [...] spraw Europy Wschodniej. [...] Po prostu moje zerwanie nastąpiło, kiedy nie mogłem już emocjonalnie wytrzymać po zobaczeniu tego, co się działo w 50. roku w Polsce ${ }^{2}$.

I don't know. This matter was extremely painful, difficult. Thinking from a perspective it doesn't seem to me that then this decision unambiguous to make. Now, as I think back, as I think from a perspective, I can see that it was difficult to say what was necessary to do. But at the same time throughout the time when I was at the

* Dr hab. prof. UŁ, e-mail: marzenaw@uni.lodz.pl; The University of Lodz, Faculty of Philology, Department of the Polish Literature of the 20 ${ }^{\text {th }}$ and 21 ${ }^{\text {st }}$; 90-236 Łódź, ul. Pomorska 171/173.

${ }^{1}$ Cf. among others. A. Fiut, W stronę Miłosza, Cracow 2003; J. Błoński, Miłosz jak świat, Cracow 1998; J. Kwiatkowski, Miejsce Miłosza w poezji polskiej, in: Poznawanie Miłosza, idem (ed.), Cracow 1985.

${ }^{2}$ Conversation of Robert Miller with Czesław Miłosz (“Głos Ameryki”, issue 23-24.04.1982), Instytut Pamięci Narodowej BU1242/81, 1.8. 
service of the Polish People's Republic, I was tormented by remorse, because the awareness of $[\ldots]$ what was happening, it was very keen, perhaps even keener than that of a majority of my fellow writers because of my knowledge of Russian and [...] the matters of Eastern Europe. [...] Simply, my breakup happened, when I couldn't emotionally stand it having seen what was happening in Poland in 1950.

The aim of this article will be the presentation of different ways of writing about Miłosz and referring to his works of the fifties, when the censorship did not allow his works and texts dedicated to him to be published. The research material consists documents of the Main Office of Control of Press, Publications and Shows ${ }^{3}$, gathered in the Archives of New Acts ${ }^{4}$ - files from the fifties, concerning leading literary and culture journals, as well as social-cultural journals of a regional reach, created on a wave of the October breakthrough, regarding the bibliography of Czesław Miłosz in the fifties. Files of journals include mainly reports from prevention control, reviews of interventions and reviews of oversights and redundant interventions and the so-called signals (the most interesting interventions each year were collected and presented to the censors for training purposes). Furthermore, files including documents of publishing houses have been examined, among others, Czytelnik, Ossolineum, Wydawnictwo Literackie, Znak, Wiedza Powszechna and religious publishing houses. Apart from the archives of censorship, another important source of knowledge are the files from the archives of the Polish Workers' Party, in which there is interesting information, first of all on the topic of the censorship of non-periodic prints (publishing houses records).

In the records of the GUKPPiW concerning journals from the fifties (including approximately 200 files, containing a few thousand documents) I found several dozen different interventions into texts connected with Miłosz. The critics most who suffered most interventions by the censors in the fifties, which involved removing the name of Miłosz, were Stefan Kisielewski, Jan Błoński, Kazimierz Wyka, Ludwik Flaszen, and Andrzej Kijowski. The least interventions come from 1952-55 because of the then rare attempts at recalling papers in journals. We can find the most in 1956-59, but record number of interventions were recorded in 1958 - a moment of confining censorship after a relatively liberal 1957, when there appeared many texts dedicated to the poet appeared along with many texts (or fragments) by him.

The fundamental meaning for determining the procedural principles with references to Miłosz have the so-called inscriptions concerning his person. Unfortunately, they were not found. They are only preserved in the files of the Polish United Workers' Party lists of positions to be removed from libraries (from 1951

\footnotetext{
${ }^{3}$ Hereinafter I use the GUKPPiW abbreviation.

${ }^{4}$ Hereinafter I use the AAN abbreviation.
} 
and 1952). Therefore, it is necessary to make an attempt at reconstructing the records through examining specific censor interventions and their justifications and following changes in those processes within the year. We have at our disposal a record taken in the mid-seventies by Tomasz Strzyżewski from the Krakow branch of censorship the copy of Book of records and recommendations, but one cannot credibly point out from which period the first records in the book come from and when they were modified as they related to Miłosz. Apart from that it is worth recalling this one known record:

2. In academic and specialist work, diaries, monographs, one can without consultations leave surnames, quotations, report on the output and activity (...) of people" [among those the instruction listed Miłosz - footnote by M.W.Ł.] (...)

a) one should not allow an overestimation of the work by the above-mentioned persons or show them in a too favorable a light.

In publications directly discussing the life and work of one of the above-mentioned people, if it has not been made in the same text - one should abide by the rule that in the preface, afterword or footnote they should give a short profile of the person specifying their position in the past or at present regarding our political system.

In specialist, cultural, literary, social-political press one can leave articles, essays, studies on the mentioned people adhering to the above-mentioned rules.

One should, however, eliminate their names and works' titles from daily papers, radio and TV, with the exception of critical information ${ }^{5}$.

We know for sure that such a guideline was in force at the time of copying the book by Strzyżewski. Taking into consideration observations made until now in the field of interventions towards Miłosz, I conclude that the remainder of the guideline from the fifties suggests to not allow his work be overestimated and not allow the poet be shown in a favourable way, as well as agreement on critical publications about the poet. Obviously one should be aware of the fact that the guidelines changed, they were modified daily, sometimes overnight, depending on the social-political situation. The paragraph suggesting assigning a negative attitude towards the poet by the government in biographies probably came from 1959 (possibly appearing for the first time in the Small General Encyclopaedia PWN. Earlier though, in the period which I am interested in, the different criteria used that depended on the character of the publications did not prove effective - the poet disappeared and re-appeared independently of whether the publications concerned were literary journals or cultural and popular newspapers. Academic works on him could not be written then. It seems helpful to assume an analogy of censorship

${ }^{5}$ Książka zapisów i zaleceń Głównego Urzędu Kontroli Prasy, Publikacji i Widowisk w Warszawie, in: Czarna księga cenzury PRL, Warsaw1981, pp. 53-54. 
actions in similar cases and times. On this premise one can assume that the first guideline for Miłosz could had been similar as the guideline on Andrzej Panufnik, which could be found in the documents of the Poznan department of censorship. It was a short guideline and forbade "publishing his name and works as well as spreading it (performing by artistic, amateur and professional groups)" .

This matter becomes complicated when we realize how instantly the authorities of the Central Committee reacted to the composer's decision: he stayed in the West on the $31^{\text {st }}$ of July, and already on the $9^{\text {th }}$ of August the Main Office of Control of Press, Publications and Shows sent to 16 departments information about this guideline. On the 11th of August the document was registered by the Provincial Office of Control of Press, Publications and Shows in Poznan with the order to enclose the guideline to the "instructions' book". In the case of Miłosz this matter did not go so fast. Three years earlier the Office of Control did not work so quickly; wrestling with internal organisation problems, it had difficulty solving growing political problems with authorities and society resulting from abuses of power during compulsory purchases of cereals, problems connected with the tight international situation, preparations for next year's elections. Such matters as the escape of a state official, even of a high rank, could in that situation wait. In the preserved documents of the censorship, shorthand records from state briefings (February and June 1951) show that there was chaos and disinformation in the Office of Control. In February 1951, after Miłosz escaped, there was a briefing concerning the protection of state, economic and military secrets ${ }^{7}$. In June, a briefing was organised again, because of a worrying "wave of oversights". Mikołajczyk, the Director of GUKPPiW, criticised the heads of departments and their officers for oversights, sloppiness and incompetence as well as for redundant interventions. Censors complained about the lack of instructions and their vagueness ${ }^{8}$. There is no reference to the "matter of Miłosz" during either the February or the June conference of censors.

In the situation when the works of Miłosz could not be published, an auxiliary research method is in investigating the reception of works, which - more or less outrightly - referred to his person or work. This method was helpful in the attempt at specifying the time of the creation of the guideline on Miłosz. It proved to be vital in the reception of the collection of poems by Witold Wirpsza entitled Polemics

\footnotetext{
${ }^{6}$ National Archives in Poznań, Provincial Office of Control of Press, Publications and Shows, ref. no. $5,1.454$.

${ }^{7}$ Sekretariat Prezesa. Odprawy krajowe 1951; Protokół z krajowej narady z czerwca 1951 roku [AAN, GUKPPiW, ref. no. 421 (vol. V)]

${ }^{8}$ Mazurek, Head from Katowice, complained: "The thing is that we should be given an instruction prepared in time, meanwhile the Provincial Office of Control of Press, Publications and Shows does not receive such help. (...) Present instructions are not adapted to the present situation. We are still having doubts and a number of difficulties in deciding whether we should comment the instruction in this or another way. [AAN, GUKPPiW, ref. no. 421 (vol. V); 1.61]
} 
and Songs, which opens with Polemic Treatise dedicated to Miłosz. A collection of poems is published and reviewed almost at the same time with Miłosz's decision to stay, so we can conclude that the guideline on Miłosz appeared in the last ten days of May 1951. Even on the $20^{\text {th }}$ of May, although it happened after the press conference and publication of the well-known article No in Parisian "Kultura", the surname of Miłosz appeared in a review neutral towards the poet written by Stanisław Czernik, but two weeks later, on the $3^{\text {rd }}$ of June, a very favourable review for the author of Rescue by Kwiryn Poraj was meticulously deleted by the censor ${ }^{9}$. Probably between those dates the guideline was issued. Censor practices are not unambiguous because in the second half of the year the name of Miłosz either appeared or became deleted. Thus, it would be difficult to find a regularity shaping that practice - it cannot be explained by either the place of publication, or sort of journal, in which a text being the subject of an intervention was published, nor the character of the reference towards the poet. The fact that Miłosz's name appeared in journals as late as in autumn can be explained with the problems of control offices - a wave of oversights was happening then. A verdict for the author of Rescue sentencing him to be forgotten actually started to be enforced one year after the poet's decision to emigrate, when his books were carefully deleted from the libraries ${ }^{10}$. However, it was not the rule because in 1952 references to the poet appeared, although in principle his name was crossed out. In a February article by Bronisław Nowicki On the poetry of Jan Huszcza, published in the "Dziś i Jutro" weekly it was deleted twice, when the poet was mentioned as one of the poets belonging to the Vilnus pre-WWII group "Żagary". The omission of the forbidden name of Miłosz in a sense extorted silence in the case of other poets from Żagary, independently of their actual attitude or ideological involvement (Jerzy Zagórski, Jerzy Putrament), also despite the fact that "Żagary" was a leftish journal. Their keeping with the simultaneous removal of the author of Three Winters would itself be too significant. Żagary's names remained, though, in different contexts, when they are not compared with the name of the emigre.

In 1953, Miłosz appeared sporadically, which probably resulted from oversights, as to publishing The Captive Mind. It was a special moment when the vigilance of censors increased because that position not only surprised national authorities but there also arose a wave of indignation. As a result of further journalists' publications in 1953, authorities deliberately blocked a national public

\footnotetext{
${ }^{9}$ It was a pseudonym of Andrzej Biernacki.

${ }^{10}$ Note on harmful and expired books, a formal letter of 9.01.52. In enclosure: "List of harmful books", pos. 226. Miłosz Czesław, in a blank "title": all [AAN, PZPR, ref. no. 237/XIX-53, 1. 9 and following.]. The list includes 472 positions. Apart from the letter it included a "List of expired books" and "List of books which should be destined to sell in second-hand bookshops" at high prices. Eventually all the books to be cleared in 1952 included 2474 items (some of them, as Miłosz, included all titles).
} 
debate about Miłosz's book, perhaps in order not to hype this topic in the stormy time after Stalin's death at the threshold of the Polish October. The response to Miłosz was postponed for two years. The first attempt was a statement of Tadeusz Drewnowski during the Plenum of the Board of the Main Polish Writers' Union, held on 10-11 June 1955, where there occurred a very distinct - although fairly discreet - idea of the necessity to repair the mistakes of the Stalinist period written about in The Captive Mind's concept of an "immanent evil" "in the system". That contradiction was one of the main disputes between the national critics during the time of the Polish October. The return of the "Miłosz case" in official discussions in journals contributed to a fundamental change of the authorities' policies towards the Polish emigration in the West along with its censorship recommendations. What is more, the person of Miłosz was about to be used deliberately in the repatriation campaign, planned by Polish authorities as a result of Moscow's directives. In August 1955, the "Kraj" Broadcasting Station was founded along with its printed equivalent (Broadcasting Station Newsletter), two institutions that had an impact on the decision about the Polish diaspora. As a fugitive from the country, Miłosz was the subject of an attack campaign exhorting him to come back. In the "Kraj" Newsletter a number of critics made references to interviews and articles. Since the letter was lodged to a foreign addressee, who realized the meaning and the creative activity of the writer in Paris, removing his name and pretending that Miłosz did not exist was pointless. That matter had an impact on national censorship. The guideline was probably then changed to the name of Miłosz: it could be published but first of all in a critical context. It was not by coincidence that Brandys's short story Before he will be forgotten opening after years official discussions about Miłosz, was published in September $1955^{11}$ - just after the "Kraj" Broadcasting Station started broadcasting. What is interesting, as we find in the archive's files, is that although the Newsletter of the Broadcasting Station did not come out in the Polish market and was subordinated directly to the Ministry of Interior, it was censored by the Audit Office, just as national papers, so it probably fell under the same regulations. The re-emigration campaign then contributed to unlock the guidelines concerning Miłosz.

The first wave of opinions about Miłosz was two-sided: there were - on the one hand - articles coming out in national journals ("Przegląd Kulturalny", "Po Prostu", "Nowa Kultura", "Życie Literackie", "Dziś i Jutro"), on the other hand - libels and assaults published in the Newsletter of the "Kraj" Broadcasting Station, thus destined for the Polish diaspora. What is more, we can distinguish two main problems trending in those publications: those were first of all critical voices towards The Captive Mind, as well as articles condemning Miłosz's attitude and his moral decisions: from the time of war, through the escape and the Parisian period.

${ }^{11}$ K. Brandys, Nim będzie zapomniany, “Nowa Kultura” IX 1955, issue 38 (September). 
Although those views decidedly dominated critical voices, as a result - restriction of the guideline on his name enabled the beginning of a discussion about a writer forbidden so far and allowed voices to come out in his defence, demonstrated by a well-known article by Flaszen On the difficult artistry of vomiting ${ }^{12}$, in which the author demanded a thorough discussion on the work of The Captive Mind's author. In response to Flaszen's demand the debaters made charges against Miłosz which could be summarized in the question: how one can discuss merits with somebody who is unworthy, immoral man? Because of that came a series of attacks on the poet from the autumn of 1955, intensified from January 1956 (Roman Zimand, Jerzy Putrament, Roman Bratny, Zygmunt Kałużyński), published in national papers, and especially close in significance to the libels of the "Kraj" Newsletter, which allows us to assume that many of the above-mentioned texts were written not because of the internal polemic need of their authors, but rather by order of the authorities, according to the current politicy towards the emigration community. A wave of attacks in the Newsletter started with the appearance of the journal and finished at the end of 1956 with a very light article by Andrzej Kuśniewicz.

In statements about Miłosz the tendency to praise his artistic talent dominated, criticising only his ideological attitude. The name of Miłosz had so far rarely been used, although it appeared mainly in the critical context (the poet was still called a traitor). A typical example of that is an intervention into an article dedicated to Miłosz written by Bratny entitled Second branch of clerks ${ }^{13}$ - a libel on the poet dressed up in a memoir form, reminding the reader of the matter of Milosz's Lithuanian passport.

Similarly, in the middle of 1956 censorship cut out favourable references to Miłosz, and removed any inspirations based on his texts. The first positive opinions about the poet appeared, sporadically at first, from the middle of 1956. First it happened by the way of rare attempts to demand national editions of Polish emigration literature. Censorship removed those demands. One should admit that that was consistent during the whole period of the Polish October. Exceptions included a text by Andrzej Barkowicz Index librorum prohibitorum ${ }^{14}$, which was rejected twice, eventually published in the June issue of "Po Prostu" - admittedly in a very cut version but with a clear demand of "releasing" prohibited material, including the works of Czesław Miłosz.

From the first half of the year references of Miłosz as a poet also appeared, in a manner more easily acceptable by the authorities and the censors they controlled . In the beginning, those were direct references, by the way of discussing other writers. Simultaneously, there was a dispute with The Captive Mind, but

\footnotetext{
${ }^{12}$ L. Flaszen O trudnym kunszcie womitowania, "Życie Literackie" 30 X 1955, issue 44.

${ }^{13}$ R. Bratny, Drugi oddzial klerków, "Po Prostu" 1956, issue 4.

${ }^{14}$ A. Berkowicz, Index Librorum Prohibitorum, "Po Prostu" 1956, issue 24.
} 
also with Brandys' short story Before he will be forgotten. In the last quarter of 1956 there occurred a fundamental commutation of censorship, also towards Miłosz. In autumn one could notice an exceptional debate: the last attack on The Captive Mind written by Zygmunt Kałużyński ${ }^{15}$ and the first nationwide firm defence of the work by Andrzej Mularczyk and Kazimierz Dziewanowski ${ }^{16}$, in addition to an exceptionally neutral article in the "Kraj" Newsletter written by Andrzej Kuśniewicz ${ }^{17}$ summarizing the discussion.

In a burst of increasing Polish October the readers in Poland were given a Christmas gift in 1956 of several important texts, which until then could not have been published. The first literary text was a summary written by Włodzimierz Maciąg of a lengthy article (published in a local journal) by Tadeusz Byrski on Miłosz's poetry (a fragment of The Seizure of Power) ${ }^{18}$ and an article by Zygmunt Lichniak about The Issa Valley ${ }^{19}$. Then, an important voice was the opinion of Julian Przyboś, the well-respected author,--who appreciated Miłosz's poetry, setting it against the lyrical-doleful emigration creative output of Skamanders.

The year 1957 was from the very beginning a time of unusual presence of Miłosz in national journals, although the majority of his texts were printed in local journals, coming out as a result of the Polish October, as in the Catholic "Tygodnik Powszechny" - not in strictly literary weeklies. Papers and anthologies published excerpts of $A$ Poetical Treatise and earlier poems, though still on the $22^{\text {th }}$ of January a censor, taking the note off from the "Ziemia i Morze" journal announcing the publication of the Treatise excerpts, justified that decision with "a possibility of generating (deletions - note by M.W.Ł.) of this position (according to the official letter of GUKP)". One could notice the uncertainty of control officers and the changing guidelines. In principle, it was forbidden to praise Miłosz for his attitude and socio-political views and advertise too much of his output, but within the space of a few months several lengthy and valuable discussions of his poems came out (Ryszard Matuszewski, Irena Sławińska, Zdzisław Łapiński, Jerzy Kwiatkowski, Jan Błoński, Marian Piechal, Henryk Vogler). Excerpts of both Treatises worked then as "winged words" (in the form of quotations or cryptoquotes) as commentaries on the disputes and public debates of the time. A Poetical Treatise was recalled in references to the poetry of the twenties, A Moral Treatise - with the skirmishes with Witkacy and existentialism. It was allowed then to argue with Miłosz, criticize him, which did not prevent the authorities from using the poet for propaganda purposes (support for Gomułka), demonstrated when the

\footnotetext{
${ }^{15}$ Z. Kałużyński, Makulatura wielkiego konfliktu, "Nowa Kultura” 1956, issue 41.

${ }^{16}$ A. Mularczyk, K. Dziewanowski, Wielki konflikt i... makulatura "Świat" 1956, issue 47.

${ }^{17}$ A. Kuśniewicz, Makulatura, historia czy ostrzeżenie, Biuletyn "Kraj” 1956, issue 49.

18 T. Byrski, O Czesławie Miłoszu, "Słowo Ludu" (Kielce), issue 306 of 24-26 XII 1956.

${ }^{19}$ Z. Lichniak, Piękno i polityka, "Kierunki” 1956, issue 32/33 (Boże Narodzenie), p. 11.
} 
January reprint-after censoring - was delivered in the BBC Letter on elections ${ }^{20}$. Miłosz appeared very often as one of the important authors of Parisian "Kultura", on the wave of relieving censorship towards information dealing with the life of emigrants, even in texts written by Jerzy Kisielewski - a great advocate of contacts with the journal of Jerzy Giedroyć. A moderate presentation of Maisons Laffite and the authors of "Kultura" was acceptable. Censors guarded that the information was not an obvious advertisement for the journal, which still had not debuted in Poland. Miłosz either appeared or was often taken off not because of him but as a representative of the non-divulged literary monthly ${ }^{21}$. Censorship cared also about not suggesting a qualitative advantage of emigrant poems over the national ones.

Important conclusions come from two articles by Leszek Goliński, presenting in the March issue of "Nowiny Literackie i Wydawnicze" Parisian and London emigration communities. In first of them entitled Hemar, Wiech and holy water $^{22}$ censorship cut out the demand of the fast re-publication in Poland of the "outstanding positions" of emigration writers - Witold Gombrowicz and Czesław Miłosz, as the suggestion of abolishing the ban on publishing works by Jerzy Giedroyć and Mieczysław Grydzewski. In the following April issue, an article entitled Literature of the absent ${ }^{23}$ by Leszek Goliński gave many favourable opinions about Miłosz, including the statement that he "is a star of the first magnitude on the emigration sky", which the censorship allowed to be published. However, it was forbidden to demand the publication of his works - censorship crossed out Selected poems by Miłosz from the previews of books from Wydawnictwo Literackie, expected for the last quarter of 1957 and Issa Valley, announced to be published in the first quarter of the following year. In the June review of Issa Valley (by Jan Błoński) a censor removed information in the footnote that the Polish edition was expected and excerpts distancing Miłosz's protagonist from the communist system. One should admit that the censorship was in that topic very consistent during the entire Polish October period.

${ }^{20}$ [Cz. Miłosz], BBC o wyborach w Polsce. Znamienny głos, “Życie Warszawy” 1957, issue 13; "Dziennik Polski” 1957, issue 14; "Trybuna Robotnicza” 1957, issue 14; "Ilustrowany Kurier Polski" 1957, issue 14; "Sztandar Ludu" 1957, issue 15; "Dziennik Bałtycki”" 1957, issue 14; "Express Ilustrowany" 1957, issue 13.

${ }^{21}$ Censorship removed not only information about Parisian "Kultura" but also about journals subsidized by national government and coming out in the West. One example of a censor's intervention is a reference of A. Rudnicki (Pisane w hotelu, "Nowa Kultura" from 14 XII 1958) that during a visit in Paris he visited the editor's office of the weekly "published for our money". The censor justified it as follows: Writing about subsidizing by us a Polish journal, coming out in Paris (...) can bring about its closure as a journal published for the money of foreign country." [Review of interventions, reviews of oversights 1958-1959 [AAN, GUKPPiW; ref. no. 656 (159/1), 1.169];

${ }^{22}$ L. Goliński, Hemar, Wiech i woda święcona, "Nowiny Literackie i Wydawnicze" 1957, issue 4.

${ }^{23}$ L. Goliński, Literatura nieobecnych, "Nowiny Literackie i Wydawnicze" 1957, issue 7. 
From the September issue of "Twórczość" an important text by Artur Sandauer was removed. In Artistic opposition in years 1944-1955, Sandauer wrote about the negative influence of censorship and the ban on importing journals from the West. The author tried to explain Miłosz's way of thinking, expressed in The Captive Mind, which also could be accepted by censors. Interventions marked on the printing brush pointed out that originally they planned to remove only fragments condemning censorship, but eventually the whole article was removed. In another October issue of "Twórczość" fragment of an article by Andrzej Kijowski disappeared, which was a broad reference to the most controversial book of Miłosz. That was a short time when one could write about Miłosz in a favourable way as a writer and artist, but all the attempts at showing the problems of The Captive Mind, especially attempts at understanding it were unwelcomed. In the Łódź "Kronika" journal (1957 issue 2) published during the Polish October came out a Miłosz's poem - You who wronged, that was unfavourable to the authorities (it was not removed by control Office). That poem was published at the end of a favourable article by Marian Piechal about the poetry of the author of Rescue. "Kronika" editorial board was probably the only one in the country that tried to publish excerpts from Miłosz's The Captive Mind. Such an attempt was taken in January 1957 and - as a result of the journal's evaluation by the Central Committee of The Polish United Workers' Party - could had been one of the reasons for the journal's liquidation. An interesting archive find is a lengthy and favourable review of Issa Valley submitted to "Chronicle" by Jarosław Marek Rymkiewicz - then a young assistant of Łódź Polish Studies. It was an article entitled Materials to the picture of Europe child - the broadest among texts so far found dedicated to Miłosz and entirely removed by censorship.

In articles dedicated to the poet in 1957 voices condemning his attitude collided with voices praising his outstanding talent and greatness. Nevertheless, that year was first of all the year of Milosz - the poet, but any voices which tried to explain or specify the meaning of The Captive Mind were eliminated by censorship. In autumn the first critical literary text by Miłosz came out after many years - in an article dedicated to Witkacy.

The beginning of 1958 was for the poet still relatively favourable. His name appeared in critical attempts to summarise the poetry written after the October Breakthrough (in discussions about visionary poetry and classical poetry, where the poet is situated on the side of "vision" and on the other time classicism). Nevertheless, the conviction that - irrespective of the divisions ordering his poetry - he was a patron saint of reasonable, intellectual poetry - finally won. Consistently, references to The Captive Mind were removed. To sum up the fundamental courses of then censor politics towards Miłosz on the base of interference one can conclude that censorship did not allow any attempts at emphasizing the importance and position of Miłosz as a 
poet, writer and thinker. However frequently his name appeared, it did not chang the context of its presentation: it was pushed back from the limelight, and the significant influence of Milosz on the Polish national literature and marginalising his voice in the most important discussions of the present times were questioned.

The attitude of censorship to Miłosz was connected with a bigger problem: with the attitude to emigration - in the spring of 1958 restrictions in presentation of the emigrant community tightened. Censorship removed not only, as in 1957, demands on the debut in "Kultura" or "Wiadomości" as publishing post-WWII prohibitions or very favourable evaluations of emigration but all important information about activity of those communities. In the March issue of "Tygodnik Powszechny" information about the critics of the young generation awarded by "Merkuriusz Polski" disappeared (national prize winners were Jan Błoński and Andrzej Kijowski - which is typical, those critics who tried to bring Miłosz back into the Polish books circulation). Removed notes included the jury's make-up, in which Czesław Miłosz had a seat. The censor justified his removal with a "GUKP order", which shows that at that time we were dealing with a transitional period: there were new directives from the headquarters, censors consulted many interventions either with chiefs of departments or over the telephone with Central Office. Miłosz's name started to be consistently removed from the majority of publications, irrespective of whether it occurred in a negative or positive context. Examples were two interventions made to texts in the "Twórczość" literary monthly: in the February issue reviews of the book Mickiewicz In World Literature. A Symposium Edited by Wacław Lednicki. (University of California Press) the suggestion about Miłosz as a poet who creatively derived from the tradition was removed, from the April issue, an allusion to Usurpers in Tale on Staff written by Kazimierz Wyka was removed. The distinct hint of the change of politics of Control Office was another example of an intervention in "Tygodnik Powszechny". Bronisław Mamoń in a review ${ }^{24}$ from the visitors' book Stanisław Ignacy Witkiewicz. Man and artist (where the Miłosz article was published as well) contained a motto derived from an excerpt from Moral Treatise. The motto was removed, which the censor justified with "the last recommendations of GUKP concerning several emigre writers". That article was written 30 April, therefore those recommendations must have appeared at the turn of the second quarter of 1958. The article by Mamon was either an example of the inconsistency of the Office or the lack of clear directives: the censor removed the motto from Miłosz, but he neither removed Miłosz's name nor quotations from the poet's article in the fundamental review text. It is surprising as the removed Moral Treatise was a work known from the official publication before Miłosz's emigration, everybody

${ }^{24}$ B. Mamoń, Człowiek i twórca, „Tygodnik Powszechny” 1958, issue 18, p. 6. 
could recall it without any effort, referring to the previous issue of "Twórczość" (what is more, the removed excerpt had been published a month earlier on the first page of "Wiadomości Literackie i Wydawnicze" dedicated to Witkacy), though left in the article was a Mamon poem that came from the emigration collection. Cuts were inconsistent, rarely justified in any reasonable way. It is worth recalling two examples of different censors' decisions in a very similar situation. Both cases concerned "Życie Literackie": in the June issue the censor removed information about Miłosz as the translator of Eliot's works, justifying the decision with "known recommendations of the GUKP", though in the August issue there was a reference that the poet has translated Miron Białoszewski into English. Therefore, it is vital that in the second case, the censor at the very beginning crossed out that information, but it was restored after the intervention of another censor, which was a sign that under certain circumstances references were allowed. Those situations must have been not specific enough, as the majority of censors far-sightedly removed everything which appeared regarding Miłosz. Still, it was out of the question to publish any of the Miłosz's works Many interesting examples of censor interventions show the exceptional interest of the Control Office in Miłosz, for example, the Catholic "Tygodnik Powszechny", which tried to refer to Czesław Miłosz in many articles by Stefan Kisielewski (Kisiel) and Marek Skwarnicki (Spodek). In 1958, a censor removed from Kisiel's column a memory sentence about Miłosz (Jubilee article about „Przekrój”), justifying, with his own intuitions and "a stand taken finally in this matter by the GUKP", which confirmed the uncertainty of censors in connection with changes in guidelines ${ }^{25}$. The censor took also the column by Skwarnicki off, which was initiated with the motto from Miłosz's poem Song about porcelain.

In the last quarter of 1958 censorship seemed to be very careful. In an anthology of patriotic poems prepared by Jan Szczawiej entitled Our name's Poland censors proposed removing Miłosz's poem Plain, and the biographic note on him. The way the biography was constructed shows the attempt at adjusting to the censorship requirements. Szczawiej limited himself to the facts from the poet's life up to the time of war, thereupon informing that "currently he has emigrated", which the censor underlined with a red pencil. It was significant also that the order of mentioned poets from group Żagary - Putrament, who because of his stature

${ }^{25}$ A characteristic and clearer example of such uncertainty is a suspension in "Życie Literackie" in 1958 of an interview with Władysław Broniewski because of distancing of the poet from his poem Word about Stalin. The censor justified: "We are sending the interview of B. Drozdowski with Broniewski withdrawn yesterday on GUKP instructions (telephone conversation with comrade Strasser). Reservations to the fragment of the interview concerning Words about Stalin underlined." Having received the response from Headquarters on the intervention card appeared a hand written note: "Allowed to be publish entirely. Krakow has been notified." Date written with pencil: 15 Jun [AAN, WUKPPiW, ref. no. 521(40/14), 1.103]. 
should have been listed rather at the end - on account of political reasons were promoted to the beginning. A similar example of an intervention was a poem of Anna Kamieńska Reading Miłosz, removed by censorship in December 1958, which the poet was going to reprint in the publishing house "Czytelnik" collection of Selected poems. The censor's reason for that was that it was "a poem in the honour of Miłosz"26. It was a crucial comment. Itshowed that literary sophistication of censors controlling literature was not the rule in those years. The poem by Kamieńska was not only a laudatory poem but also a polemic against Miłosz. The censor, explaining the intervention, focussed on the name of the emigre poet.

A particular phonemenon involved the publication of books, which set in the period of bigger liberalization, come out after tightening censorship. The period between permission printing and the book coming out was sometimes six months. In such situations, if the text did not concern a thorny political question, it was not confiscated. Examples included the first volume of Works by Jarosław Iwaszkiewicz (Poems), which included Private letter with a favourable fragment about Miłosz and Poetic thing, where Miłosz appeared in a positive context in the article by Jarosław Marek Rymkiewicz.

Interventions in 1958 showed more than once the decisive problems in the Control Office. Cuts were inconsistent, rarely sensibly explained. After a relatively liberal 1957 came a time of increasing limitations and chaos. Meaningful testimony on censorship problems but also difficulties with censorship was given at the $9^{\text {th }}$ General Convention of the Polish Writers' Union in December 1958 in Wrocław, (dedicated in large part to a discussion about censorship). Kisielewski demanded openness and "clear specification of criteria of censorship acting", paid attention to the lawless policies of censors towards publishing houses using the preventive censorship "for a rainy day" - one removes more than it is necessary and there are no clear rules and limits of these interventions. He also complained about the too assiduous acceptance of censorship by the publishing houses. Among the discontinued books Kisielewski mentioned, among other, Matter of imagination by Kazimierz Wyka - essays about poetry withdrawn by the author, after he was told to cross out everything which concerned Miłosz's works. It recalled also the removal from the publishing plans emigration books of Miłosz: Selection of poems and Issa Valley. Demanding publishing at least Miłosz's occupation poems, he testified

I would like to notice the matter of emigration. These criteria are still changing. Once it is allowed to mention Gombrowicz or Miłosz, another time it does not. If there are 8 millions of Poles in exile, dissociating completely from their output and

${ }^{26}$ Comparison of interventions made by the GUKP in non-periodical publications $1 \mathrm{X}-10 \mathrm{XII}$ 1958 [AAN, GUKPPiW, ref. no. 591 (60/2), 1.6]. 
books would be a suicide politics, it is against the reason of state of Polish People's Republic and everything ${ }^{27}$.

Despite numerous demands at the December convention of the Union, in the end not much was achieved. After negotiations with the Office Wyka published in 1959 a collection of essays about literature entitled Thing about imagination without a sketch about Miłosz (it did not come out until the second edition of the book, in 1977). A typical example - on the one hand - of writers" helplessness towards censorship, on the other hand, the schizophrenia and helplessness of the offcials working in that office was an example of the intervention in the article by Jan Błoński Theatrical Criticism of Peiper, set to be published in the "Dialog" theatre journal in 1959. In that article the censor removed the first sentence - a quotation from Poetical Treatise by Miłosz. It is interesting that in the final version the quotation remained with the author's name, but the title of the work which it came from... was removed. The question is, with which a censor's note one could justify such practice - becomes opened.

Despite the insistent attempts of authorities and censors, the absent poet was present to a bigger extent than could be seen from the statistics of his publications in the fifties (three short fragments of The Seizure of Power-1956; Ode from Poetical Treatise, several poems and translations in press and anthologies, a sketch about Witkacy -1957). His image was created by various forms, using strategies of silence and identification in the comments of literary critics and journalists: summaries, reviews, columns, literary diary, satirical texts, even parodies of po$\mathrm{ems}^{28}$, however first of all works of the next generation young writers studying with difficulty the early and emigration works of the The Captive Mind's author.

\section{Bibliography}

Archiwum Państwowe w Poznaniu, WUKPPiW, ref. no. 5.

AAN, GUKPPiW, ref. no. 421, ref. no. 421; ref. no. 591 (60/2); ref. no. $656(159 / 1)$

AAN, PZPR, ref. no. 237/XVIII-180; ref. no. 237/XIX-53.

Berkowicz Andrzej, Index Librorum Prohibitorum, "Po Prostu" 1956, issue 24.

Brandys Kazimierz, Nim będzie zapomniany, "Nowa Kultura" IX 1955, issue 38.

Bratny Roman, Drugi oddziat klerków, "Po Prostu" 1956 issue 4.

Byrski Tadeusz, O Czesławie Miłoszu, "Słowo Ludu" (Kielce) no 306 on 24-26 XII 1956.

Conversation of Roberta Miller with Czesław Miłosz ("Głos Ameryki”, 23-24.04.1982 r.), Instytut

Pamięci Narodowej BU1242/81, 1. 8.

${ }^{27}$ Shorthand record from the session of the $9^{\text {th }}$ General Convention of the Polish Writers' Union held on the $15^{\text {th }}$ and $16^{\text {th }}$ December 1958 in Wrocław (AAN, PZPR, ref. no. 237/XVIII-180, 1. 33-34).

${ }^{28}$ Cf. K. Wyka, [Czesław Miłosz, W pogardzie], in: idem, Duchy poetów podstuchane, Cracow 1959, pp. 100-101; M. Piechal, [Czesław Miłosz, Pomnik Trytona], in: idem, Diabeł za skóra, Warsaw 1959, p. 63. 
Czarna księga cenzury PRL, Warszawa 1981, pp. 53-54.

Flaszen Ludwik, O trudnym kunszcie womitowania, "Życie Literackie” 30 X 1955, issue 44.

Goliński Leszek, Hemar, Wiech i woda święcona, "Nowiny Literackie i Wydawnicze" 1957, issue 4.

Goliński Leszek, Literatura nieobecnych, "Nowiny Literackie i Wydawnicze" 1957, issue 7.

Kałużyński Zygmunt, Makulatura wielkiego konfliktu, "Nowa Kultura” 1956, issue 41.

Kuśniewicz Andrzej, Makulatura, historia czy ostrzeżenie, Biuletyn "Kraj” 1956, issue 49.

Lichniak Zygmunt, Piękno i polityka, "Kierunki” 1956, no 32/33 (Boże Narodzenie), p. 11.

Mamoń Bronisław, Człowiek i twórca, "Tygodnik Powszechny" 1958, issue 18, p. 6.

Mularczyk Andrzej, Dziewanowski Kazimierz, Wielki konflikt i... makulatura "Świat" 1956, issue 47.

Miłosz Czesław, BBC o wyborach w Polsce. Znamienny głos, “Życie Warszawy” 1957, issue 13.

Marzena Woźniak-Łabieniec

\section{Censorship Towards Czesław Miłoszin Poland in the Fifties after Having Chosen the Emigration}

\section{(Summary)}

This article shows the outline of problems connected with censoring Czesław Miłosz's literary output in Poland in the 1950s, when the poet breaks off with the national government and chooses political asylum in France, becoming an émigré. The article looks into (in the space of decade) the periods of particularly tightened control towards Miłosz, shows how the censorship was tightening and relaxing when it came to his name. In the Polish October several poems and an excerpt from the novel The Seizure of Power was published, though - despite publishing advertisements - none of the poet's books came out.

Keywords: Czesław Miłosz, censorship after 1945, censorship towards literature, literary life after 1945, literary criticism 